\title{
Investigation of Natural Radioactivity and Dose Assessment over Steel Making Region
}

\author{
Abdelazem E. A. Mohamed1,2, Mohammed A. Halato², Siddig T. Kafi² \\ ${ }^{1}$ Department of Forensic Physics, Regional Forensic Laboratory, General Administration of Forensic Evidence, Sudan Police, \\ Khartoum, Sudan \\ ${ }^{2}$ Department of Medical Physics, Faculty of Sciences and Technology, Al-Neelain University, Khartoum, Sudan \\ Email: abdelazem41@gmail.com,mhalato@gmail.com,Stawer.Kafi@gmail.com
}

How to cite this paper: Mohamed, A.E.A., Halato, M.A. and Kafi, S.T. (2020) Investigation of Natural Radioactivity and Dose Assessment over Steel Making Region. Open Journal of Ecology, 10, 397-403. https://doi.org/10.4236/oje.2020.107025

Received: January 19, 2020

Accepted: June 21, 2020

Published: June 24, 2020

Copyright (C) 2020 by author(s) and Scientific Research Publishing Inc. This work is licensed under the Creative Commons Attribution International License (CC BY 4.0).

http://creativecommons.org/licenses/by/4.0/ (c) (i) Open Access

\begin{abstract}
This study aims to measure the radiation dose over several steel-making factories in Khartoum region, Sudan. The authors used different techniques to detect the harmful Natural Occurring Radioactive Material (NORM) emitting through the steel-making process. While, an X-ray Diffractometer was utilized to detect the NORM in the isotopes clay elite and magnesio-ferrite over slag steel waste and soil. The worker dose was measured by using polimaster device and it was detected $56.448 \mathrm{mSv}$ per year. And backpack mobile monitored the background over the waste and it was $0.048 \mu \mathrm{Sv} / \mathrm{h}$ in accounting mode. In another hand gamma spectrometer with a high purity germanium detector detected the average of activity concentration of natural radionuclide over the slag steel waste and $\mathrm{K}-40$ of it is $321 \pm 3 \mathrm{~Bq} / \mathrm{Kg}$, Th-232 is $20.6 \pm 5$ $\mathrm{Bq} / \mathrm{Kg}, \mathrm{Ra}-226$ is $15.2 \pm 4 \mathrm{bq} / \mathrm{Kg}, \mathrm{Cs}-137$ is $3.33 \pm 7 \mathrm{~Bq} / \mathrm{Kg}$, and over soil around the waste the concentration of $\mathrm{K} 40, \mathrm{Ra} 226$, Th232 was $(185 \pm 3,12.6$ \pm 7 , and $12.0 \pm 5) \mathrm{Bq} / \mathrm{Kg}$, respectively.
\end{abstract}

\section{Keywords}

Steel Making, Slag Steel, NORM, Radiation Dose, Radiation Survey

\section{Introduction}

The steel industries are highly successful in Sudan that leads to take it as one of the economic backbones, although steel made involving in the several activity according to United Nation Conference on Trade and Development (UNCTD) report [1]. In addition, there are different environmental impact risks according to steel-making as shown in the previous studies as one of the enhanced sources of Naturally Occurring Radioactive Material (NORM) [2], furthermore, some 
studies shown that the blast furnace slag contained a low level of long-lived radionuclides from the uranium and thorium series. The ${ }^{210} \mathrm{Po}$ and ${ }^{210} \mathrm{~Pb}$ levels in dust collected from the blast furnace off-gases are generally lower than those from the sinter plant [3]. Although the regional agency for the environmental protection of Veneto was studied concerning NORM in integrated steel workers in coke production residue blast furnace dust and sinter dust in an enhanced level of ${ }^{210} \mathrm{~Pb}$ and ${ }^{210} \mathrm{Po}$ in dust and residue sample, it was more than $40 \mathrm{~Bq} / \mathrm{g}$ [4]. Also the investigation of the presence of the natural isotopes such as $40 \mathrm{~K},{ }^{226} \mathrm{Ra}$, ${ }^{232} \mathrm{Th}$, and ${ }^{238} \mathrm{U}$ as well as artificial isotopes such as ${ }^{60} \mathrm{Co},{ }^{137} \mathrm{Cs}$, and ${ }^{192} \mathrm{Ir}$ in the Steel Mills of CMC-Croatia was carried out [5].

In the similar case we found that the International Commission on Radiological Protection (ICRP) recommended that dose limits as an effective dose of about $20 \mathrm{mSv}$ in a year averaged over 5 years, with no more than $50 \mathrm{mSv}$ in each one year of occupational. Exceeding the limit of $1 \mathrm{mSv}$ and exceptionally higher effective dose could be allowed in a year provided that the average over 5 years does not exceed $1 \mathrm{mSv}$ in a year. Also, the reference level effective dose should be controlled by action on exposure pathway to reducing doses, and it will be taken as a reference level for radiological emergency when it ranged between $20-100$ $\mathrm{mSv}$ [6]. Some cases refer to the low dose level of iron or steel NORM activity generally when it compared to ${ }^{226} \mathrm{Ra}$ level in gold mining concentrations which is up to $1.7 \mathrm{~Bq} / \mathrm{g}$ also the annually dose was recorded in range about $0.04 \mathrm{mSv}$ in same field [7].

In particular, NORM contaminated dusts may be generated during handling or processing of the steel and breathed into the body, slag steel and other non-ferrous components can become contaminated with low specific activity scale (LSA) [8].

Although, the radionuclide present in NORM in slag waste giving of ionizing radiation which can interact with human cell and the hazard that may cause for human and environment depend on radionuclide type, activity, the radiation wich emit, how that radiation interacts [9]. Also Scrap metal industry such as tubing, valves and heat exchangers from various process industries may contain scales with enhanced levels of natural radionuclides, the particular radionuclide and their concentrations would depend on the origin of the scrap, since objects from nuclear industries and the uncontrolled releases of radioactive sources may be added to this material, which may be recycled, the scrap metal industry is a source of variable and heterogeneous releases of radionuclides into the environment emission, the natural radionuclides present in the raw materials or wastes of the steel industries are those of the ${ }^{238} \mathrm{U}$ and ${ }^{232} \mathrm{Th}[10]$.

Natural occurring Radioactive Material is one of the radiation sources released from processed materials, and affected workers, the public and the environment mainly require radiation control and regulation [11].

In this study, authors investigated the presence of the NORM over steel-making 
region, and measured worker radiation dose limits during the steel melting.

\section{Materials and Methods}

\subsection{Measurements Tools}

The existence of NORM in steel-making waste was measured by using different recent calibrated Techniques, for instance, X-ray diffractometer (XRD-7000) devices (Shimadzu, Japan), polimaster and backpack technique device model 1014 controller 1021 detector design BdKn-05 to Neutron, BdKG-11m to Gamma and polimaster (model pm $1703 \mathrm{~m}-01$ serial $74088 \mathrm{GNM}$ ). The devices are also utilized in Sudanese Nuclear and Radiological Regulatory Authority (SNRA), High Purity Germanium (HPGE) spectrometer with the lead shield from (BSI) Baltic Scientific Instruments.

\subsection{Experimental}

Two methods of evaluating external exposures from naturally occurring radionuclides have been used. polimaster and backpack devices to a simply summarize directly measured external gamma dose rates due to steel production.

All the measurement were taken $1 \mathrm{~m}$ above the ground and steel melting oven, also, the slag steel and soil sample were collected from selective steel factory area, sample pulverized and packed in $1 \mathrm{~kg}$ by mass in the cylindrical plastic containers of radius 3 inch and height 3.5 inch, which sits on the (3 inch $\times 3$ inches) high purity germanium (HPGe) detector with geometry the containers are sealed for one week to ensure radioactive equilibrium between the parent radionuclides and their gaseous daughter decay products in the uranium and thorium series, although the small amount of sample directed measured in XRD device to detected the clay isotopes amount [12].

\section{Results}

\subsection{Backpack Result}

Table 1 shown the Backpack Result over 6 slag steel waste position in order to record the waste background radiation over the waste and the average of NORM background in Khartoum steel waste about 0.48 micro Sivert/hour.

Table 1. Backpack result over the slag steel waste in different position.

\begin{tabular}{cc}
\hline Sample NO & Bag Back Reading $\mu$ Sv/h \\
\hline $\mathbf{1}$ & 0.048 \\
$\mathbf{3}$ & 0.039 \\
$\mathbf{4}$ & 0.0405 \\
$\mathbf{5}$ & 0.042 \\
$\mathbf{6}$ & 0.045 \\
\hline
\end{tabular}




\subsection{XRD Result}

Figure 1 shown the XRD slag steel Homogenies sample result after used Match3! Analysis program [13] the result shown that the slag steel included the elite isotopes clay form and magnesio-ferrite.

\subsection{The Hyper Pure Germanium Detector Results}

Table 2 \& Table 3 shown the radioactive concentration of the slag steel waste and soil sample the Result shown the existence of the K-40 and Ra-226, Th-232 and their activity.

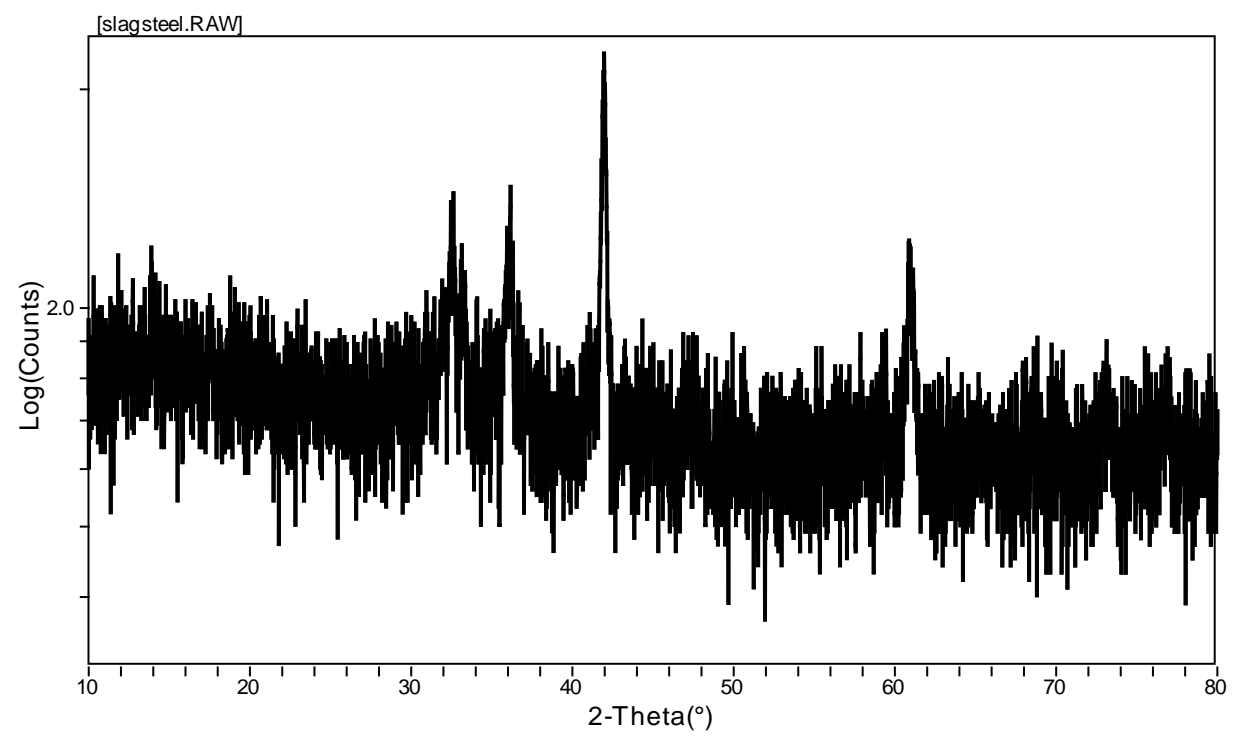

Figure 1. XRD analysis of the homogeneous 6 slag steel sample from Giad industrial area.

Table 2. HPG slag steel sample result.

\begin{tabular}{ccccc}
\hline Nuclide per line & $\begin{array}{c}\text { Area Impulse } \\
\text { Gamma energy } \\
(\mathrm{kev})\end{array}$ & $\begin{array}{c}\text { Average of Activity } \\
\text { indifferent position } \\
(\mathrm{Bq} / \mathrm{Kq})\end{array}$ & $\begin{array}{c}\text { Relative Uncertainty } \\
(\%)\end{array}$ & MDA (Bq) \\
\hline K40 & 1520 & 185 & 3 & 0.33 \\
Ra226 & 1960 & 12.6 & 7 & 0.04 \\
Th232 & 3490 & 12.0 & 5 & 0.69 \\
\hline
\end{tabular}

Table 3. HPG soil sample around steel factories area result.

\begin{tabular}{ccccc}
\hline Nuclides/Lines & Area, [impulse] & $\begin{array}{c}\text { Average of Activity } \\
\text { indifferent position Bq/kg }\end{array}$ & Relative un certainty, & MDA, Bq \\
\hline k-40 & 1670 & 321 & 3 & 10.51 \\
Th-232 & 1580 & 20.6 & 5 & 0.25 \\
Ra-226 & 1240 & 15.2 & 4 & 0.06 \\
Ra-228 & $307 \mathrm{~cd}$ & 10.2 & 7 & 3.38 \\
Cs-137 & 284 & 3.33 & 7 & 0.74 \\
\hline
\end{tabular}




\subsection{Polimaster Result}

Table 4 shown the polimaster detector reading of the radiation dose in different directions over the oven during melting the scrap and the average of the dose is (2.45 mR) during the steel-making which is worked 12 hours per day approximately twice in a week in below calculation can measure the dose during the factory operation.

\section{Calculation}

The equivalent dose $(\mathrm{H})$ is calculated by multiplying the absorbed dose (D) by the occupation time $(\mathrm{T})$.

$$
H=D \times T \quad[14]
$$

The Polimaster dosimeter gives dose rate readings in Dose Rate micro-Ream per hour $(\mu \mathrm{R} / \mathrm{h})$. The Ream radiation dose unit $(R)$ can be converted to Sievert radiation dose unit $\left(S_{V}\right)$ according to the following equation [15]:

$$
100 R=1 S v \quad[15]
$$

Based on Table 4 the average of the radiation dose during steel making poling is about $2.45 \mathrm{mR}$. According to this we can calculate the following:

1) The average dose per day when the factory operated 12 hour is

$$
12 \times 2.45=29.4 \mathrm{mR}=0.294 \mathrm{mSv}
$$

2) The average dose per week is

$$
29.4 \times 2(\text { when operated } 2 \text { days per week })=58.8 \mathrm{mR}=0.588 \mathrm{mSv}
$$

3) The average Dose per Month is

Table 4. Polimaster result during steel melting in Aljerif steel making factory.

\begin{tabular}{cccc}
\hline CPS, Neutron & Dose Rate $(\mu \mathrm{R} / \mathrm{h})$ & Dose $(\mathrm{mR})$ & CPS, Gamma \\
\hline 0.02 & 8.00 & 2.28 & 7 \\
0.03 & 8.00 & 2.28 & 7 \\
0.05 & 8.00 & 2.28 & 8 \\
0.05 & 8.00 & 2.28 & 19 \\
0.04 & 6.00 & 2.28 & 6 \\
0.03 & 31.00 & 2.29 & 36 \\
0.03 & 516.00 & 2.29 & 23 \\
0.03 & 280.00 & 2.29 & 317 \\
0.03 & 410.00 & 2.29 & 330 \\
0.03 & 885.00 & 2.29 & 1403 \\
0.03 & 16.00 & 2.29 & 20 \\
0.03 & 10.00 & 2.29 & 12 \\
3.50 & 144.00 & 2.29 & 4 \\
0.03 & 16.00 & 2.29 & 20 \\
\hline
\end{tabular}


$58.8 \times 8($ when operated 8 days per month $)=470.4 \mathrm{mR}=4.704 \mathrm{mSv}$

4) The annual calculated dose is

$470.4 \times 12$ when worked 12 days per year $=5644.8 \mathrm{mR}=56.448 \mathrm{mSv}$

\section{Discussion}

This study was curried out in three different positions (Giad industrial area in coordinate 15,019'12.4" $\mathrm{N} 3249^{\prime} 59.7 " \mathrm{E}$, Aljerif East in Khartoum incoordinate $15,034^{\prime} 21.4^{\prime \prime} \mathrm{N} 32,033^{\prime} 10.9^{\prime \prime} \mathrm{E}$, Jelly industries area in coordinate $1600.7^{\prime} 21.2^{\prime \prime} \mathrm{N}$ 32,039'29.5"E).

The radiation dose in this case up to recommended dose given in UNSCEAR publication as shown in Equation (6), this unusual activity related to existence of NORM in slag steel waste because they were using the slag steel waste with scrap materials and raw material during steel making process, Figure 1 and Table 2, Table 3 show the existence of this NORM as form of clay elite and Th and U series.

Table 1 show that the measurement reading over slag steel waste and scrap in different area position the result within the normal range when comparing it with previous survey in Khartoum survey reading

\section{Conclusion}

This result indicates evidence for radiological significant existence of NORM over the steel making factories and this existence increases the worker dose level $6.448 \mathrm{mSv}$ over the IAEA recommended dose level. The dose recording and reporting practices are governed by regulations and may differ for various categories of workers depending on the anticipated level of exposure in the IAEA documents [16] [17]. There are also guidelines for dose recording which may vary among countries so this may significantly affect the reported values of collective dose and these factors are technique use dosimeter, all the radiation hazard indices estimated in this study are higher than the acceptable limits, it can therefore be concluded that steel making waste is not safe for use as materials for building and rood construction until applied radiation safety requirement.

\section{Acknowledgements}

I acknowledge professor Siddig Tawer Kafi whose encouraged to completed this work special thanks to my friend Elxander F.I. Osman who read and provided useful advice on earlier draft of this articles, extended thank to my friend Mohaid Ali who support me to finished this work, and I would like to thanks my parent and my wife for them patient.

\section{Conflicts of Interest}

The authors declare no conflicts of interest regarding the publication of this paper. 


\section{References}

[1] UNCTAD (2015) Investment Policy Review-The Sudan, United Nations Conference on Trade and Development (UNCTAD) Investment Policy Reviews. Geneva.

[2] IAEA (2007) Naturally Occurring Radioactive Material (NORM V). Proceedings of an International Symposium, Seville, 19-22 March 2007, 351-354.

[3] Er, I.N.T., et al. (2005) Code of Practice on Safety and Health in the Iron and Steel Industry Code of Practice on Safety and Health in the Iron and Steel Industry.

[4] Radiation Protection Series and Radiation Protection Series, Management of Naturally Occurring Radioactive Material (NORM) (Australian Government, Australian Radiation Protection and Nuclear Safety Agency).

[5] Trotti, F., et al. (2007) A Study Concerning NORM in Integrated Steelworks 1. c, 2-4.

[6] Sofilić, T., et al. (2011) Monitoring of Radionuclides in Carbon Steel Blooms Produced by Eaf Process. Journal of Mining and Metallurgy, Section B: Metallurgy, 47, 125-136. https://doi.org/10.2298/JMMB110101005S

[7] Wrixon, A.D. (2008) New ICRP Recommendations. Journal of Radiological Protection, 28, 161. https://doi.org/10.1088/0952-4746/28/2/R02

[8] UNSCEAR (2010) Sources, Effects and Risks of Ionizing Radiation 2010 Report. UNSCEAR Report, I.

[9] Tawfik, A.A. and Ahmed, E.M. (2014) Radiological Doses and Risk Assessment of NORM Scrap Metal by Using RESRAD-RECYCLE Computer Code. Open Journal of Modelling and Simulation, 2, 34-42. https://doi.org/10.4236/ojmsi.2014.22006

[10] Hassan, A.K., Fares, S.S. and El-Rahman, M.A. (2014) Natural Radioactivity Levels and Radiation Hazards for Gypsum Materials Used in Egypt. Journal of Environmental Science and Technology, 7, 56-66. https://doi.org/10.4236/ns.2014.61002

[11] Underhill, P.T. (2018) Naturally Occurring Radioactive Material, Naturally Occurring Radioactive Material. Routledge, Abingdon-on-Thames. https://doi.org/10.1201/9780203746042

[12] Mohamed, A.E.A., Halato, M.A. and Kafi, S.T. (2020) Investigations of the Radioactive Presence and Heavy Metallic Materials in Merowe Dam Area. Open Journal of Ecology, 10, 89-96. https://doi.org/10.4236/oje.2020.103007

[13] Poloko, N., Danha, G. and Gaogane, T. (2019) Processing and Characterization of Chalcopyrite $\left(\mathrm{CuFeS}_{2}\right)$ Sample from Botswana. Procedia Manufacturing, 35, 488-493. https://doi.org/10.1016/j.promfg.2019.05.070

[14] Alshahri, F. and El-Taher, A. (2019) Investigation of Natural Radioactivity Levels and Evaluation of Radiation Hazards in Residential-Area Soil near a Ras Tanura Refinery, Saudi Arbia. Polish Journal of Environmental Studies, 28, 25-34. https://doi.org/10.15244/pjoes/83611

[15] Marsh, J.W. and Birchall, A. (2009) Uncertainty Analysis of the Absorbed Dose to Regions of the Lung per Unit Exposure to Radon Progeny in a Mine. HPA-RPD-054.

[16] IAEA (2006) Assessing the Need for Radiation Protection Measures in Work Involving Minerals and Raw Materials. Safety Report Series No. 49.

[17] Radiation Protection and Phosphate Industry (2013) Safety Reports Series No. 78 Radiation Protection and Management of NORM Residues in the Phosphate Industry Iaea Safety Standards and Related Publications. 